\title{
Meal frequency and associated factors among children 6-23 months in Tahtay michew district, northern Ethiopia, 2018
}

Ermyas Brhane ( $\sim$ ermiyasbr@gmail.com )

Aksum University https://orcid.org/0000-0003-3431-8087

Teklit Grum

Aksum University

Teklehaymanot Huluf Abraha

Aksum University

Gebrekiros Aregawi

Aksum University

Research article

Keywords: meal frequency, children 6-23 months, Tahtay Michew district

Posted Date: September 15th, 2020

DOI: https://doi.org/10.21203/rs.3.rs-70779/v1

License: (1) This work is licensed under a Creative Commons Attribution 4.0 International License.

Read Full License 


\section{Abstract}

\section{Background}

The term meal frequency is used to describe the adequacy of complementary feedings among children. In the absence of adequate meal frequency young children are susceptible to malnutrition like stunting, wasting, micronutrient deficiencies and associated morbidity and mortality. More half of Ethiopian children did not receive age appropriate minimum meal frequency. Therefore, the aim of this study is to determine minimum meal frequency and associated factors among children 6-23 months in Tahtay Michew district, Northern Ethiopia.

Methods

A community based cross sectional study was conducted among systematically selected 981 mothers with index children 6-23 month. An interviewer- administered structured questionnaire was used to collect data. 24 hours dietary recalls was used to determine minimum meal frequency. Crude and Adjusted Odds Ratio with the corresponding 95\% confidence interval were computed. In the multivariable analysis, variables with less than 0.05 P-value were considered statistically significant.

Results

Minimum meal frequency was $68 \%$ [95\% Cl: 64.9, 70.9\%]. Wealth index $(\mathrm{AOR}=1.69,95 \% \mathrm{Cl}=1.09,2.61)$, growth monitoring follow up $(A O R=1.98,95 \% \mathrm{Cl}=1.41,2.79)$ and mothers knowledge $(A O R=2.15,95 \%$ $\mathrm{Cl}=1.51,3.04)$ were factors significantly associated with minimum meal frequency.

Conclusion and recommendation

The proportion of children who received the minimum meal frequency was found low. Improving the wealth status of families and encouraging all mothers to attend growth monitoring follow ups are important for improving meal frequency and dietary diversity.

\section{Introduction}

\section{Background}

Minimum meal frequency is a proxy indicator of the adequacy of complementary foods among children [1]. The World Health organization (WHO) recommend that children should get the age appropriate minimum meal frequency that is two or more times for breastfed infants 6 to 8.9 months of age, three or more times for breastfed children 9 to 23.9 months, and four times for non-breastfed children 6 to 23.9 months [2].

Inappropriate feeding practices are important risk factors for malnutrition and associated morbidity and mortality among infants and young children, and more than two-thirds of children deaths related to 
malnutrition are associated with inappropriate feeding practices during the first 24 months of life [3]. In addition poor nutrition in the early life is associated with irreversible damage, including shorter adult height, lower attained schooling, reduced adult income, and decreased offspring birth weight [4].

In many countries in the world less than one fourth of children 6-23 months of age meet the criteria for meal frequency and dietary diversity [5], and case is more sever in Africa especially in sub-Saharan countries [6]. In case of Ethiopia despite many efforts were done to improve minimum meal frequency, a significant number of Ethiopian children did not receive age appropriate minimum meal frequency [7-9].

Despite the fact that adequate meal frequency in the early life is very important for healthy growth and development of children; little is known about meal frequency and factors associated with it and so far no similar study was done in the study area. Therefore the aim is to determine minimum meal frequency and factors associated with minimum meal frequency.

\section{Methods And Materials}

\section{Study design and setting}

A community based cross sectional study was conducted from January, 22, 2018 to February, 30, 2018.

The study was conducted in Tahaty Michew district found in central zone of Tigray Regional State one of the nine regional states in Ethiopia located at a distance of $1041 \mathrm{~km}$ from Addis Ababa (the capital city of Ethiopia). The weather condition of the district is semi highland. Maize, teff and sorghum are the staple cereals in the district and more than $95 \%$ of the population is living with farming activities. Tahtay Michew district has 17 kebele (the smallest administration unit in Ethiopia) administrations.

\section{Sample size determination and sampling technique}

The sample size was calculated by using the single population proportion formula. Therefore, the total sample size was calculated with assumption of $95 \%$ confidence level, $4 \%$ margin of error, prevalence of minimum meal frequency $45 \%$ [7], design effect of 1.5 and non response rate of $10 \%$ of $1.65 \%$. Finally the sample size was 981.

Out of seventeen kebeles found in the district eight kebeles was included in the study using lottery method. The number of study participant was allocated for each Kebele based on proportional to population size allocation methods by using community based demographic and Health related information registration prepared by Health Extension workers as a sampling frame. Rapid census was conducted 07 days before the actual data collection on the kebeles first to identify the target House hold. Finally child-mother pairs was selected from each Kebele by using systematic random sampling technique after giving code for each house hold which has child from 6 months to 23 months.

\section{Measurement and data collection procedure}


Data was collected from mothers who have at least one child in age 6-23 months from each household by direct interviewing. Those who have more than one child in age range of 6 to- 23 month one child were selected randomly by lottery method. A pre-tested structured questionnaire adapted from different literatures [6-17] was used to collect data. The questionnaire was prepared in English e and translated in to Tigriga the (local language). Later on, it was translated back to English to check its consistency. The Tigrigna version of questionnaire was used to collect the data. Eight data collectors and two supervisors who are speakers of the local language were recruited during the data collection period.

Minimum meal frequency of the child was determined by asking the mother (care taker) how many times the child took solid, semi-solid, or soft foods in the $24 \mathrm{~h}$ preceding the survey. Accordingly, two or more times for breastfed infants 6 to 8.9 months of age, three or more times for breastfed children 9 to 23.9 months, and four times for non-breastfed children 6 to 23.9 months were considered as the children received the minimum meal frequency [2]. Wealth index was determined using Principal Component Analysis (PCA) by considering household assets, such as quantity of cereal products, house, livestock and agricultural land ownership [10].

Knowledge on complementary feeding of the mother was determined by asking questions related on complementary feeding and meal frequency. A mother or care taker answers above mean for the knowledge related questions was considered as knowledgeable [10]. Maternal social capital was assessed using six questions related social capital. A mother or care taker answers above mean for the social capital related questions was considered as having good social capital [8].

\section{Data management and analysis}

After all returned questionnaire was checked for completeness and consistency, data was data were coded and entered in to EPI INFO version 7 and then, exported to STATA-12 statistical software. During descriptive analysis, continuous variables were summarized using mean and standard deviation while categorical variables were summarized using percentages. The effect of each variable on meal frequency was assessed using bi-variable logistic regression model. Before inclusion of predictors to multivariable logistic regression analysis, fulfillment of model assumption was checked using Homers-lemeshow test. Multi co- linearity was checked using Variance Inflation Factors (VIF). Those variables with $\mathrm{P} \leq 0.1$ in bivariable logistic regression model were entered spontaneously in multivariable logistic regression model to measure the effect of each category of each variable on meal frequency. Variables with $P<0.05$ in multivariable logistic regression analysis were considered as the factor associated with meal frequency. Measure of association was calculated using adjusted odds ratio (AOR) with 95\% confidence interval.

\section{Results}

\section{Socio-demographic and socio-economic characteristics of study participants}


Out of 954 mothers participated in the study; 949 of the participants gave complete response with the response rate of $96.7 \%$. The mean age $[ \pm S D]$ of the children was $13.7 \pm 4.59$ months. The mean age $[ \pm$ $\mathrm{SD}$ ] of the mother was $29.74 \pm 6.66$ years. The mean family size [ \pm SD] was $4.75 \pm 1.7$ persons.

Eight hundred forty eight [89.4\%] of mothers were married, 878 [92.5\%] were Orthodox Christian in religion and five hundred twenty six [55.4\%] mothers were farmers in their occupation. Regarding to educational status three hundred thirty one [34.9\%] of mothers had no formal education [Table 1]. 
Table 1

Socio-demographic and socio economic characteristics of participants on meal frequency and associated factors in Tahtay Michew district, northern Ethiopia, 2018

\begin{tabular}{|c|c|c|c|}
\hline Variable & Category & Number & Percent \\
\hline \multirow[t]{3}{*}{ Mothers age in years } & $15-24$ & 236 & 24.9 \\
\hline & $25-34$ & 467 & 49.2 \\
\hline & $\geq 35$ & 246 & 25.9 \\
\hline \multirow[t]{3}{*}{ Age of index child in months } & $6-11$ & 359 & 37.8 \\
\hline & $12-17$ & 355 & 37.4 \\
\hline & $18-23$ & 235 & 24.8 \\
\hline \multirow[t]{2}{*}{ Sex of index child } & Male & 486 & 51.2 \\
\hline & Female & 463 & 48.8 \\
\hline \multirow[t]{3}{*}{ Family size in persons } & $2-4$ & 495 & 52.2 \\
\hline & $5-7$ & 376 & 39.6 \\
\hline & $\geq 8$ & 78 & 8.2 \\
\hline \multirow[t]{2}{*}{ Religion } & Orthodox & 878 & 92.5 \\
\hline & Muslim & 71 & 7.5 \\
\hline \multirow[t]{4}{*}{ Marital status } & Married & 848 & 89.4 \\
\hline & Divorced & 76 & 8 \\
\hline & Separated & 17 & 1.8 \\
\hline & Widowed & 8 & 0.8 \\
\hline \multirow[t]{4}{*}{ Mothers educational status } & No formal education & 331 & 34.9 \\
\hline & Primary school (1-8) & 317 & 33.4 \\
\hline & Secondary school $(9-12)$ & 252 & 26.6 \\
\hline & Diploma and above & 39 & 5.2 \\
\hline \multirow[t]{5}{*}{ Husband educational status } & No formal education & 182 & 21 \\
\hline & Primary school (1-8) & 340 & 39.3 \\
\hline & Secondary school $(9-12)$ & 266 & 30.8 \\
\hline & Diploma & 40 & 4.6 \\
\hline & Degree and above & 37 & 4.3 \\
\hline
\end{tabular}




\begin{tabular}{|c|c|c|c|}
\hline \multirow{2}{*}{ Variable } & \multirow[b]{2}{*}{ Category } & \multirow{2}{*}{ Number } & \multirow[b]{2}{*}{ Percent } \\
\hline & & & \\
\hline \multirow[t]{5}{*}{ Mothers employment status } & Farmer & 526 & 55.4 \\
\hline & House wife & 244 & 27.7 \\
\hline & Self employed & 70 & 7.4 \\
\hline & Daily worker & 55 & 5.8 \\
\hline & Government employed & 54 & 5.7 \\
\hline \multirow[t]{5}{*}{ Husband employment status } & Farmer & 587 & 67.9 \\
\hline & Self employed & 104 & 12 \\
\hline & Daily worker & 95 & 11 \\
\hline & Government employed & 79 & 9.1 \\
\hline & No & 114 & 12 \\
\hline \multirow[t]{3}{*}{ Wealth index } & Low & 317 & 33.4 \\
\hline & Middle & 323 & 34 \\
\hline & High & 309 & 32.6 \\
\hline
\end{tabular}

\section{Health service utilization related characteristics}

The mean parity of mothers was 2.84 children [SD \pm 1.67 children]. 856 [90.2\%] of the mothers had one or more Antenatal care (ANC) follow up when they were pregnant for the index child. 792 [83.5\%] of the mothers had delivered at health facility for the index child. 430 [45.3\%] of the mothers had one or more Postnatal care (PNC) follow up after birth to the index child. 583 [61.4\%] of the mothers had take the index child one or more times for growth monitoring follow up [Table 2]. 
Table 2

Health service utilization characteristics of participants on meal frequeency and associated factors in Tahtay Michew district, northern Ethiopia, 2018.

\begin{tabular}{|c|c|c|c|}
\hline Variable & Category & Number & Percent \\
\hline \multirow[t]{2}{*}{ ANC follow up } & Yes & 856 & 90.2 \\
\hline & No & 93 & 9.8 \\
\hline \multirow[t]{2}{*}{ Number of ANC follow up } & $1-3$ & 322 & 37.6 \\
\hline & $\geq 4$ & 534 & 62.4 \\
\hline \multirow[t]{2}{*}{ Birth preparedness } & Yes & 821 & 86.5 \\
\hline & No & 128 & 13.5 \\
\hline \multirow[t]{2}{*}{ Place of delivery of index child } & Health facility & 792 & 83.5 \\
\hline & Home & 157 & 16.5 \\
\hline \multirow[t]{3}{*}{ Birth order of index child } & First & 255 & 26.9 \\
\hline & Second to fifth & 613 & 64.6 \\
\hline & $\begin{array}{l}\text { Sixth and } \\
\text { above }\end{array}$ & 81 & 8.5 \\
\hline \multirow[t]{3}{*}{ Birth interval between bigger and index child in months } & $12-36$ & 242 & 34.9 \\
\hline & $37-60$ & 336 & 48.4 \\
\hline & $\geq 61$ & 116 & 16.7 \\
\hline \multirow[t]{2}{*}{ PNC follow up } & Yes & 430 & 45.3 \\
\hline & No & 519 & 54.7 \\
\hline \multirow[t]{2}{*}{ Number of PNC follow up } & $1-2$ & 388 & 90.2 \\
\hline & $\geq 3$ & 42 & 9.8 \\
\hline \multirow[t]{2}{*}{ Counseling about child feeding during ANC or PNC follow up } & Yes & 482 & 50.8 \\
\hline & No & 467 & 49.2 \\
\hline \multirow[t]{2}{*}{ Growth monitoring follow up } & Yes & 583 & 61.4 \\
\hline & No & 366 & 38.6 \\
\hline \multirow{2}{*}{$\begin{array}{l}\text { Counseling about child feeding during Growth monitoring } \\
\text { follow up }\end{array}$} & Yes & 523 & 89.7 \\
\hline & No & 60 & 10.3 \\
\hline \multirow{2}{*}{$\begin{array}{l}\text { HEW home visit and counseling about child feeding within a } \\
\text { month }\end{array}$} & Yes & 434 & 45.7 \\
\hline & No & 515 & 54.3 \\
\hline
\end{tabular}




\section{Knowledge, media exposure and social capital related characteristics}

Five hundred forty nine [57.9\%] of the mothers had good knowledge on infant and child feeding. 307 [32.3\%) of the mothers had satisfactory media exposure. 468 [49.3\%] of the mothers posses good social capital like community group membership, having emotional/economic support from individuals, and citizenship activities and cognitive social capital (i.e., trust, social harmony, and sense of belonging) in the past 12 months.

\section{Minimum meal frequency}

The number of children who received the recommended minimum meal frequency for their age was 645 [68\% (95\% Cl: 64.9, 70.9\%)] [Figure1].

\section{Factors associated with minimum meal frequency}

In the bi-variable logistic regression analysis eight variable namely number of wealth index, ANC follow up, place of delivery, growth monitoring follow up, health extension worker home visit, mothers knowledge on child feeding, satisfactory media exposure and mothers social capital in the last 12 months were significantly associated with minimum meal frequency at $95 \% \mathrm{CL}$ and p value $\leq 0.1$. In the multivariable logistic regression analysis only three variables namely wealth index, growth monitoring follow up and mothers' knowledge were significantly associated with minimum meal frequency at P-value $<0.05$ and $95 \%$ confidence level.

Specifically children belonging to rich wealth status families were1.69 time $(A O R=1.69,95 \% \mathrm{Cl}=1.09$, 2.61) more likely to receive the recommended minimum meal frequency, compared to poor wealth status families. Mothers who toke their index child to growth monitoring follow-ups were 1.98 times ( $A O R=1.98$, $95 \% \mathrm{Cl}=1.41,2.79)$ more likely to provide minimum meal frequency compared to their counterparts. Mothers who had good knowledge on childe feeding were 2.15 times $(A O R=2.15,95 \% \mathrm{Cl}=1.51,3.04$ ) more likely to provide minimum meal frequency compared to mothers who had poor knowledge on child feeding [Table 3]. 
Table 3

Factors associated with minimum meal frequency among 6-23 months of children, in Tahtay Michew District, Northern Ethiopia, 2018

\begin{tabular}{|c|c|c|c|c|c|}
\hline \multirow[t]{2}{*}{ Variable } & & \multicolumn{2}{|c|}{$\begin{array}{l}\text { Minimum meal } \\
\text { frequency }\end{array}$} & \multirow[t]{2}{*}{ COR with 95\% Cl } & \multirow[t]{2}{*}{$\begin{array}{l}\text { AOR with } 95 \% \\
\mathrm{Cl}\end{array}$} \\
\hline & & Yes (\%) & No (\%) & & \\
\hline \multirow[t]{3}{*}{ Wealth index } & Poor & $189(59.6)$ & $128(40.4)$ & 1 & 1 \\
\hline & Middle & $218(67.5)$ & $\begin{array}{l}105 \\
(32.5)\end{array}$ & $1.41(1.01,1.94)$ & $1.27(0.87,1.84)$ \\
\hline & Rich & $238(77)$ & $71(23)$ & $2.27(1.61,3.21)$ & $1.69(1.09,2.61)^{\star}$ \\
\hline \multirow{2}{*}{$\begin{array}{l}\text { Number of ANC } \\
\text { follow up }\end{array}$} & $1-3$ & $208(64.6)$ & 114(35.4) & 1 & 1 \\
\hline & $\geq 4$ & $398(74.6)$ & $136(25.4)$ & $\begin{array}{l}1.604(1.188 \\
2.165)\end{array}$ & $\begin{array}{l}1.25(0.91- \\
1.75)\end{array}$ \\
\hline \multirow[t]{2}{*}{ Place of delivery } & $\begin{array}{l}\text { Health } \\
\text { facility }\end{array}$ & $574(72.5)$ & $218(27.5)$ & $\begin{array}{l}3.189(2.246 \\
4.53)\end{array}$ & $\begin{array}{l}1.55(0.92- \\
2.62)\end{array}$ \\
\hline & Home & $71(45.2)$ & $86(54.8)$ & 1 & 1 \\
\hline \multirow[t]{2}{*}{$\begin{array}{l}\text { Growth monitoring } \\
\text { follow up }\end{array}$} & Yes & $449(77)$ & $134(23)$ & $\begin{array}{l}2.906(2.193 \\
3.852)\end{array}$ & $\begin{array}{l}1.98(1.41 \\
2.79)^{\star}\end{array}$ \\
\hline & No & $196(55.6)$ & $170(44.4)$ & 1 & 1 \\
\hline \multirow[t]{2}{*}{ HEW home visit } & Yes & $323(74.4)$ & $111(25.6)$ & $\begin{array}{l}1.744(1.318 \\
2.307)\end{array}$ & $1.11(0.79,1.55)$ \\
\hline & No & $322(62.5)$ & 193(37.5) & 1 & 1 \\
\hline \multirow[t]{2}{*}{ Knowledge } & Good & $437(79.6)$ & $112(20.4)$ & $\begin{array}{l}3.602(2.707 \\
4.792)\end{array}$ & $\begin{array}{l}2.15(1.51 \\
3.04)^{\star}\end{array}$ \\
\hline & Poor & $208(52)$ & 192(48) & 1 & 1 \\
\hline \multirow[t]{2}{*}{$\begin{array}{l}\text { Satisfactory media } \\
\text { exposure }\end{array}$} & Yes & $241(78.5)$ & $66(21.5)$ & $\begin{array}{l}2.151(1.568 \\
2,95)\end{array}$ & $0.99(0.66,1.89)$ \\
\hline & No & $404(63)$ & $238(37)$ & 1 & 1 \\
\hline \multirow{2}{*}{$\begin{array}{l}\text { Maternal Social } \\
\text { capital }\end{array}$} & Good & $361(77.1)$ & 107(22.9) & $2.34(1.765,3.103)$ & $1.31(0.93,1.87)$ \\
\hline & Poor & $284(59)$ & $197(41)$ & 1 & 1 \\
\hline
\end{tabular}

\section{Discussion}

This community based cross-sectional study found that the proportion of children who received the recommended minimum meal frequency and dietary diversity for their age were 68\% [95\% Cl: 64.9, 
70.9\%]. Wealth index, growth monitoring follow up and mothers' knowledge were independent determinants of minimum meal frequency.

The proportion of children who received meal frequency was in line with findings from southern Ethiopia [17] and Arsei negele [8]. However, the finding is slightly lower from the findings from northwestern Ethiopia[10]. The difference could be explained by significant proportion of mothers $(42.1 \%)$ in this study lacks the necessary knowledge about child complementary feeding.

The finding is also higher from findings from North West Ethiopia[9], from secondary analysis EDHS 2016 [7], western Ethiopia[18] and Nigeria[19].The difference might be due to the fact that the EDHS were nationwide survey on a larger sample. In addition, the EDHS were conducted on culturally different population, which may inhibit child feeding practices while, the current study was conducted on almost culturally homogenous population with similar feeding practices.

Children belonging to rich wealth status family were1.69 times more likely to receive the recommended minimum meal frequency compared to poor wealth status families. supportive findings were found from study conducted in Dangila town [9], north west Ethiopia[10], Ethiopia[11] ,east Africa region [6] and Haiti [12]. This may due to the fact that rich wealth status families are more likely to be food secure and have the capacity to purchase different consumables goods for their families.

Growth monitoring follow-ups was one of the determinant factors for meal frequency. Mothers who toke their index child to growth monitoring follow-ups were 1.98 times more likely to provide minimum meal frequency compared to their counterparts. Supportive findings were reported from studies in northwest Ethiopia[10] and Nepal [20]. This could be explained by growth monitoring and promotions are supported by individual counseling and community conversations which are likely to enhance the understanding of mothers about how many they should feed their children.

\section{Conclusion And Recommendation}

The proportion of children who received the recommended meal frequency was found low as measured by WHO indicators. Wealth index, growth monitoring follow up and mother's knowledge about child feeding were independent determinants of minimum meal frequency.

Therefore, policy makers (government) should do to improve the wealth status of families. Health professionals and health extension workers needs to support mothers to have the right knowledge on child feeding practice by providing timely and appropriate counseling during PNC and growth monitoring follow ups.

\section{Abbreviations}

ANC: Antenatal Care 
AOR: Adjusted Odds Ratio

CF: Complementary Feeding

Cl: Confidence Interval

COR: Crude Odds Ratio

GM: Growth Monitoring

HEW: Health Extension Worker

NGO: Non-Governmental Organization

PNC: Post Natal Care

UNICEF: United Nations Children's Emergency Fund

VIF: Variance Inflation Factor

WHO: World Health Organization

\section{Declarations}

\section{Availability of data and materials}

The datasets during and/or analyzed during the current study is available from the corresponding author on reasonable request.

\section{Ethics approval and consent to participate}

Before commencement of the study, ethical clearance was obtained from Institutional Review board of collage of health science and CSH Aksum University. Formal letter was obtained from Tahtay Michew district health office administration to get permission. In addition, written informed consent was obtained from each study participant to confirm willingness for participation after explaining the objective of the study.

\section{Consent to publish}

Not applicable.

\section{Competing interests}

The authors declare no competing interests 


\section{Funding}

Not applicable

\section{Contributions}

EB conceived the idea in mind, involved in proposal development, supervised data collection, and participated in data analysis and interpretation of the data. TG, TH and GA assisted in the design of the study, proposal writing, data analysis, and interpretation of the study. All authors were responsible for data collection, initial analysis and drafting of manuscript. All authors reviewed and approved the final manuscript.

\section{Acknowledgment}

We are grateful to the study participants, data collectors and supervisors who agreed to take part in this study.

\section{References}

1. World Helath Organization. Infant and young child feeding: model chapter for textbooks for medical students and allied health professionals: World Health Organization; 2009.

2. World Helath Organization. Indicators for assessing infant and young child feeding practices: part 1: definitions: conclusions of a consensus meeting held 6-8 November 2007 in Washington. DC: World Health Organization; 2008.

3. United Nations International Children's Emergency Fund. Infant and young child feeding: programming guide. New York: UNICEF; 2011. pp. 17-8.

4. Victora CG, Adair L, Fall C, Hallal PC, Martorell R, Richter L, et al. Maternal and child undernutrition: consequences for adult health and human capital. The lancet. 2008;371(9609):340-57.

5. Jones AD, Ickes SB, Smith LE, Mbuya MN, Chasekwa B, Heidkamp RA, et al. World Health Organization infant and young child feeding indicators and their associations with child anthropometry: a synthesis of recent findings. Matern Child Nutr. 2014;10(1):1-17.

6. Gewa CA, Leslie TF. Distribution and determinants of young child feeding practices in the East African region: demographic health survey data analysis from 2008-2011. Journal of Health Population Nutrition. 2015;34(1):6.

7. Central Statistical Agency,Ethiopia Demographic and Health Survey2016,in October 2016:Addis Ababa,Ethiopia.

8. Kassa T, Meshesha B, Haji Y, Ebrahim J. Appropriate complementary feeding practices and associated factors among mothers of children age 6-23 months in Southern Ethiopia, 2015. BMC 
Pediatr. 2016;16(1):131.

9. Beyene M, Worku AG, Wassie MM. Dietary diversity, meal frequency and associated factors among infant and young children in Northwest Ethiopia: a cross-sectional study. BMC Public Health. 2015;15(1):1007.

10. Belew AK, Ali BM, Abebe Z, Dachew BA. Dietary diversity and meal frequency among infant and young children: a community based study. Ital J Pediatr. 2017;43(1):73.

11. Aemro M, Mesele M, Birhanu Z, Atenafu A. Dietary diversity and meal frequency practices among infant and young children aged 6-23 months in Ethiopia: a secondary analysis of Ethiopian demographic and health survey 2011. Journal of nutrition and metabolism. 2013;2013.

12. Heidkamp RA, Ayoya MA, Teta IN, Stoltzfus RJ, Marhone JP. Complementary feeding practices and child growth outcomes in Haiti: an analysis of data from Demographic and Health Surveys. Matern Child Nutr. 2015;11(4):815-28.

13. Issaka Al, Agho KE, Page AN, Burns L, Stevens P, Dibley GJ. MJ. Determinants of suboptimal complementary feeding practices among children aged 6-23 months in seven francophone W est $A$ frican countries. Matern Child Nutr. 2015;11:31-52.

14. Ng CS, Dibley MJ, Agho KE. Complementary feeding indicators and determinants of poor feeding practices in Indonesia: a secondary analysis of 2007 Demographic and Health Survey data. Public Health Nutr. 2012;15(5):827-39.

15. Victor R, Baines SK, Agho KE, Dibley MJ. Factors associated with inappropriate complementary feeding practices among children aged 6-23 months in T anzania. Matern Child Nutr. 2014;10(4):545-61.

16. Demilew YM, Tafere TE, Abitew DB. Infant and young child feeding practice among mothers with 024 months old children in Slum areas of Bahir Dar City, Ethiopia. International breastfeeding journal. 2017;12(1):26.

17. Mekonnen TC, Workie SB, Yimer TM, Mersha WF. Meal frequency and dietary diversity feeding practices among children 6-23 months of age in Wolaita Sodo town, Southern Ethiopia. Journal of Health Population Nutrition. 2017;36(1):18.

18. Ayana D, Tariku A, Feleke A, Woldie H. Complementary feeding practices among children in Benishangul Gumuz Region, Ethiopia. BMC Res Notes. 2017;10(1):335.

19. Udoh EE, Amodu OK. Complementary feeding practices among mothers and nutritional status of infants in Akpabuyo Area. Cross River State Nigeria SpringerPlus. 2016;5(1):2073.

20. Gautam KP, Adhikari M, Khatri RB, Devkota MD. Determinants of infant and young child feeding practices in Rupandehi, Nepal. BMC Res Notes. 2016;9(1):135.

\section{Figures}




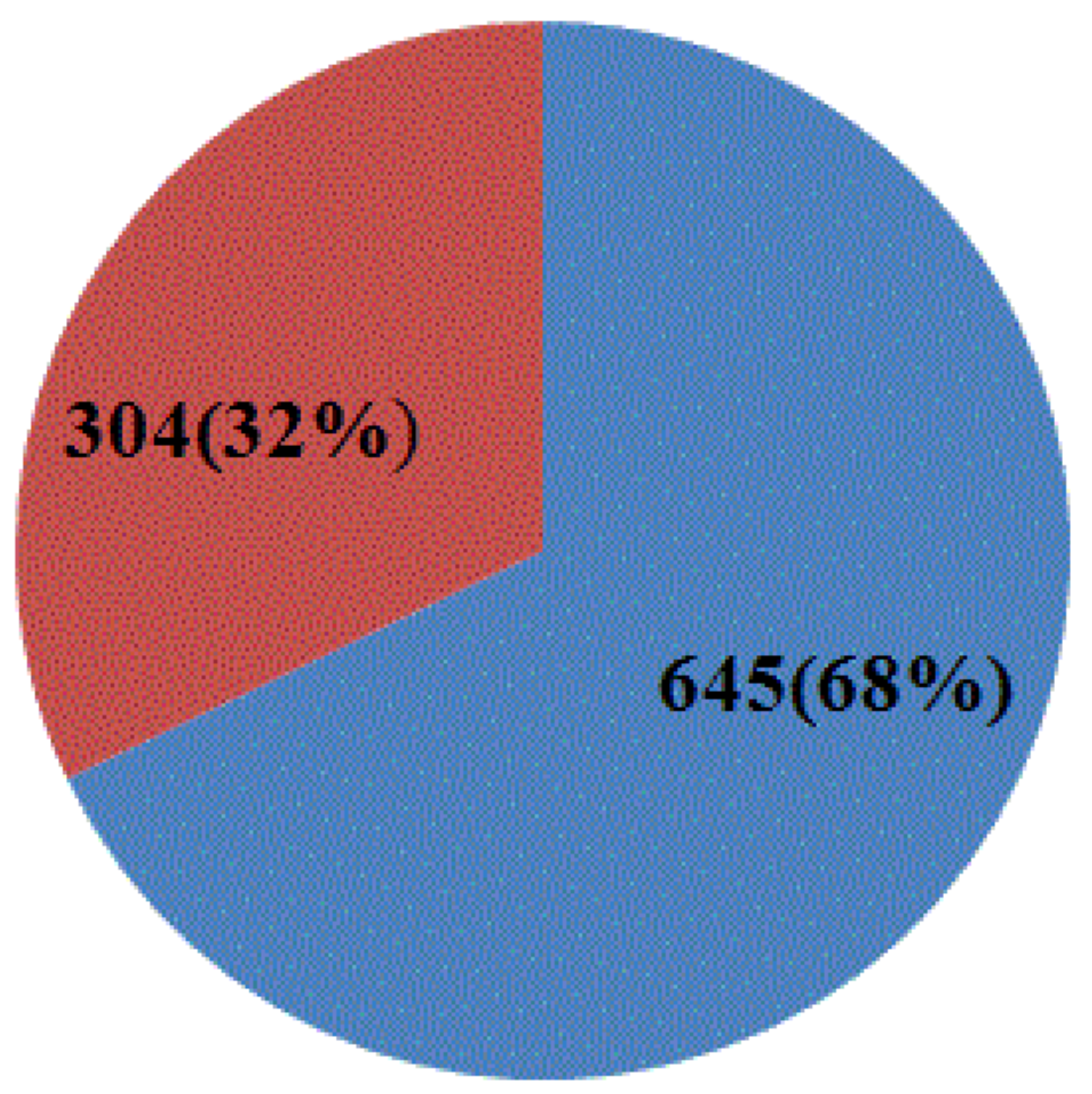

Figure 1

Minimum meal frequency among children 6-23 months in Tahtay michew district, northern Ethiopia, 2018

\section{Supplementary Files}

This is a list of supplementary files associated with this preprint. Click to download.

- Minimummealfrequencywithmininumdata.dta 